Article

\title{
Fique Fabric: A Promising Reinforcement for Polymer Composites
}

\author{
Sergio Neves Monteiro ${ }^{1}$, Foluke Salgado de Assis ${ }^{1}$, Carlos Luiz Ferreira ${ }^{1}$, \\ Noan Tonini Simonassi ${ }^{1}$, Ricardo Pondé Weber ${ }^{1}$, Michelle Souza Oliveira ${ }^{1}$, \\ Henry A. Colorado ${ }^{2}$ and Artur Camposo Pereira ${ }^{1, *}$ \\ 1 Materials Science Program, Military Institute of Engineering, IME, Praça General Tibúrcio 80, Urca, \\ Rio de Janeiro 22290-270, Brazil; snevesmonteiro@gmail.com (S.N.M.); foluke.assis@hotmail.com (F.S.d.A.); \\ cferreira@ime.eb.br (C.L.F.); noantoninisimonassi@gmail.com (N.T.S.); rpweber@ime.eb.br (R.P.W.); \\ oliveirasmichelle@gmail.com (M.S.O.) \\ 2 CCComposites Laboratory, Universidad de Antioquia, UDeA, Calle 70, No. 52-21, \\ Medellin 050010, Colombia; henry.colorado@udea.edu.co \\ * Correspondence: camposo.artur@gmail.com; Tel.: +55-22-999-290-508
}

Received: 6 February 2018; Accepted: 24 February 2018; Published: 28 February 2018

\begin{abstract}
A relatively unknown natural fiber extracted from the leaves of the fique plant, native of the South American Andes, has recently shown potential as reinforcement of polymer composites for engineering applications. Preliminary investigations indicated a promising substitute for synthetic fibers, competing with other well-known natural fibers. The fabric made from fique fibers have not yet been investigated as possible composite reinforcement. Therefore, in the present work a more thorough characterization of fique fabric as a reinforcement of composites with a polyester matrix was performed. Thermal mechanical properties of fique fabric composites were determined by dynamic mechanical analysis (DMA). The ballistic performance of plain woven fique fabric-reinforced polyester matrix composites was investigated as a second layer in a multilayered armor system (MAS). The results revealed a sensible improvement in thermal dynamic mechanical behavior. Both viscoelastic stiffness and glass transition temperature were increased with the amount of incorporated fique fabric. In terms of ballistic results, the fique fabric composites present a performance similar to that of the much stronger $\operatorname{Kevlar}^{\mathrm{TM}}$ as an MAS second layer with the same thickness. A cost analysis indicated that armor vests with fique fabric composites as an MAS second layer would be 13 times less expensive than a similar creation made with $\operatorname{Kevlar}^{\mathrm{TM}}$.
\end{abstract}

Keywords: fique fabric; composites; polyester matrix; thermal dynamic mechanical behavior; ballistic performance

\section{Introduction}

The beginning of this new century witnessed a surge in research works dedicated to the use of fibers extracted from plants in engineering applications. Several specialized and review articles [1-15] emphasized the use of these natural lignocellulosic fibers and their fabrics as reinforcements of polymer composites, competing with synthetic fibers. Environmental sustainability goals associated with lower cost, societal benefits, and some technical advantages favor the substitution of natural fiber and fabric for glass fiber [16] and aramid fabric [17]. Industrial components, mainly in automobile fabrication [18-20], increasingly employ natural fiber and fabric composites. A specific industrial sector in which fibers and fabrics are of relevance is that of armor vests. Originally, fiber glass was extensively used [21,22] and carbon fiber-reinforced polymer composites were also considered [23]. Today, synthetic aramid fabrics such as $\operatorname{Kevlar}^{\mathrm{TM}}$ (Du Pont, Richmond, VA, USA) [24] and Twaron ${ }^{\mathrm{TM}}$ (Teijin Aramid, Conyers, GA, USA) [25] as well as ultra-high molecular weight polyethylene fibers, such 
as Spectra $^{\mathrm{TM}}$ (Spectra Energy Corporation, Houston, TX, USA) [26] and Dyneema ${ }^{\mathrm{TM}}$ (DSM Dyneema LLC, Stanley, NC, USA) [27], are major choices for personal armor vests. Recent publications [28-33] revealed that natural fibers as well as corresponding fabrics-reinforced polymer composites display comparable ballistic performance to Kevlar ${ }^{\mathrm{TM}}$. In spite of numerous publications dedicated to this subject, the growing interest for engineering applications is continuously demanding research works on less common promising natural fibers and fabrics. An example is the relatively unknown fiber extracted from the leaves of an Andean plant (Furcraea andina). This fique fiber has been brought to attention for its potential as a composite reinforcement [34-39]. Figure 1 illustrates: (a) fique plantation in Colombia and (b) a bundle of fique fibers extracted from the leaves of the plant. For practical use, the fique fabric is yearlong found in the Colombian market and largely available for common applications, mostly as sackcloth for agricultural products. Owing to its national importance, the federal government of Colombia controls both the price and quality of the fique fiber, which is stored and distributed for industrial processing, including as a textile. The extraction cost, from plantation to clean fibers (see Figure $1 \mathrm{a}, \mathrm{b}$ ), is around US $\$ 0.14$, while the consumer price varies from US $\$ 0.36$ to US $\$ 0.45$. Fiber surface modification [34] and thermal degradation [35] as well as bending [36] and tensile [37,38] properties of fique fiber-reinforced composites were preliminarily investigated. Moreover, an inverse correlation between the density and the diameter of fique fibers was established [39]. As for fique fabric, either woven or non-woven, characterization and properties of polymeric-reinforced composites are still not found in the scientific literature. In particular, thermal dynamic mechanical properties, which are important for engineering applications, were not mentioned for fique fabric in the only review [40] dedicated to polymer composites reinforced with less common natural fiber-based materials. These properties might be obtained by dynamic mechanical analysis (DMA) and could provide viscoelastic behavior as well as temperature effect on distinct dynamic moduli. Any possible engineering application of fique fabric-reinforced composites, particularly in personal armors, will demand additional information on thermal dynamic mechanical and ballistic properties, which is the objective of the present work.
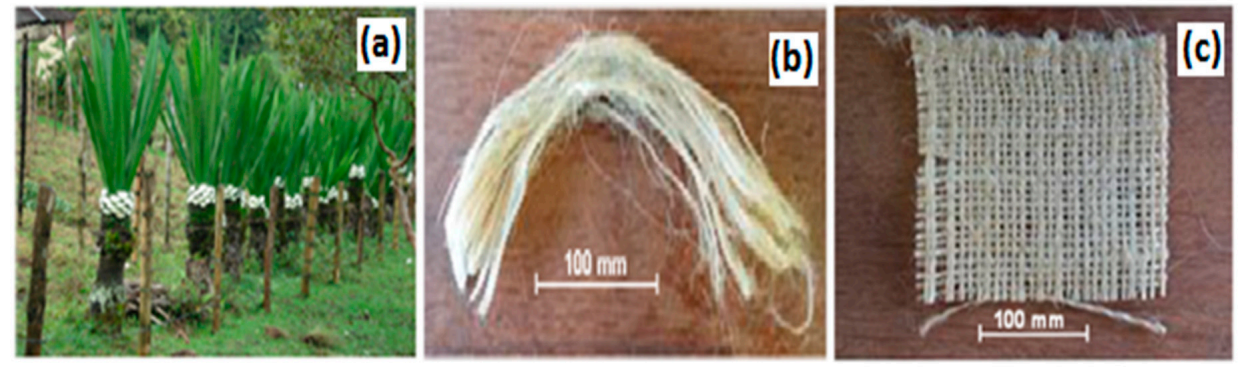

Figure 1. Plantation of fique (Furcraea andina) in Colombia (a), bundle of fique fibers (b), and as-received piece of fique fabric (c).

\section{Materials and Methods}

\subsection{Materials Source and Process}

Fique fabric commercially available in Colombia was supplied by Compañia de Empaques, Itagüí, Antioquia, Colombia. A piece of as-received fabric is shown in Figure 1c. An average equivalent diameter of $0.18 \mathrm{~mm}$ and an average density of $667 \mathrm{~kg} / \mathrm{m}^{3}$ for the fique fiber, Figure $1 \mathrm{~b}$, were reported elsewhere [39]. The areal density of the plain-woven fabric, Figure 1c, investigated in this work was found to be $0.036 \mathrm{~kg} / \mathrm{m}^{2}$. An isophtalic polyester resin hardened with $1 \%$ methyl-ethyl-ketone, fabricated by Dow Chemical and supplied by Resinpoxy, Rio de Janeiro, Brazil, was used as the composite matrix. Composites were prepared by accommodating the previously dried fabric $\left(60{ }^{\circ} \mathrm{C}\right.$ for $\left.24 \mathrm{~h}\right)$ in a steel mold, and then pouring the still fluid resin-hardener mixture between fabric layers. In this way, $120 \times 150 \times 50 \mathrm{~mm}^{3}$ plates of laminate composites with 10,20 , and $30 \mathrm{vol} \%$ fique 
fabric associated with 4,8 , and 12 layers were respectively produced. These plates were kept under $3 \mathrm{MPa}$ pressure for $24 \mathrm{~h}$, at room temperature $\left(25^{\circ} \mathrm{C}\right)$, until complete solid cure. Test samples were cut from the laminate composite plates and standard flexural specimens with 10, 20, and $30 \mathrm{vol} \%$ fabric, as well as neat polyester for control, were prepared.

\subsection{Dynamic Mechanical Analysis (DMA)}

DMA tests were performed in fique fabric composites, using flexural specimens according to standard. All analyses were conducted in triplicate to evaluate the degree of dispersion in corresponding curves. Less than $10 \%$ difference was found between curves for identical conditions, basically confirming the same results. Therefore, only one typical curve is used to illustrate each condition.

Each DMA test was carried out in the interval from -20 to $160{ }^{\circ} \mathrm{C}$ in a model Q/800 TA Instruments (New Castle, DE, USA) in three-point flexural mode, $1 \mathrm{~Hz}$ frequency, and a heating rate of $3 \mathrm{~K} / \mathrm{min}\left(3^{\circ} \mathrm{C} / \mathrm{min}\right)$ under nitrogen atmosphere. The storage modulus $\left(\mathrm{E}^{\prime}\right)$, loss modulus $\left(\mathrm{E}^{\prime \prime}\right)$, and tangent delta curves were provided by the equipment. Prismatic standard specimens with dimensions of $50 \times 13 \times 3 \mathrm{~mm}$ were used for the tests.

\subsection{Ballistic Tests}

In addition to DMA, preliminary ballistic tests were carried out according to the NIJ 0101.06 standard using $7.62 \times 51 \mathrm{~mm}^{2}$ NATO military ammunition with a $9.7 \mathrm{~g}$ projectile propelled from a gun barrel. The tests were conducted at the Brazilian Army shooting facility, CAEX, in the Marambaia Peninsula, Rio de Janeiro, with three samples of 10 and $20 \mathrm{vol} \%$ of fique fabric for each type of multilayered armor system (MAS) [41,42]. Figure 2a shows the exploded view of the ballistic test setup while Figure $2 b$ illustrates, schematically, the MAS composed of a front ceramic followed by a layer of fique fabric composites and backed by an aluminum alloy sheet. The MAS is set as a target together with a block of so-called clay witness that simulates a human body and should only allow penetration to a certain depth. According to the standard NIJ 0101.06, the measured depth of indentation is limited to $44 \mathrm{~mm}$ in order to avoid lethal trauma to the MAS wearer. Measurements were performed with a laser sensor caliper with $0.01 \mathrm{~mm}$ of precision.
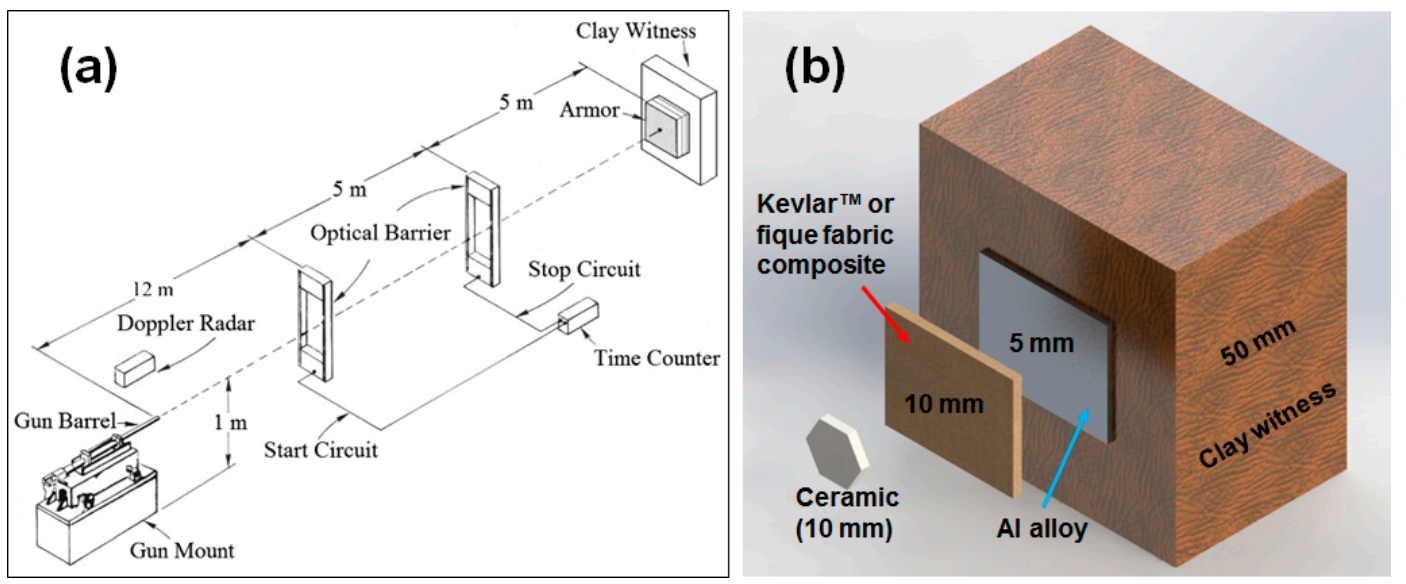

Figure 2. (a) Schematic exploded view of the ballistic experimental setup and (b) schematic illustration of the investigated multilayered armor system (MAS), as a target placed ahead of a clay witness block.

\subsection{Fracture Microscopy}

The ruptured surface of each MAS component after the ballistic test was analyzed by scanning electron microscopy (SEM) in a model QUANTA FEG250 Fei (Thermo Fisher Scientific, Hillsboro, OR, USA) microscope operating with secondary electrons at $20 \mathrm{kV}$. 


\section{Results and Discussion}

\subsection{Dynamic Mechanical Analysis (DMA)}

Figures 3-5 respectively show the DMA storage modulus $\left(E^{\prime}\right)$, loss modulus ( $\left.E^{\prime \prime}\right)$, and tangent delta $(\tan \delta)$ curves for the neat polyester resin and fique fabric-reinforced composites. Figure 3 compares the variation of the storage modulus $\left(\mathrm{E}^{\prime}\right)$ with temperature for the neat polyester and different composites investigated. For all temperature levels, from $25^{\circ} \mathrm{C}$ up to $70{ }^{\circ} \mathrm{C}$, the $\mathrm{E}^{\prime}$ values for the fique fabric composites are significantly higher than that of the neat polyester resin. In fact, the value of $\mathrm{E}^{\prime}$ is directly related to the material's ability to withstand mechanical loads with recoverable viscoelastic deformation. Consequently, the results in Figure 3 above room temperature indicate a substantial raise in the viscoelastic stiffness of the polyester with increasing incorporation of fique fabric, without loss in recoverable deformation. Moreover, while an accentuated decrease in stiffness begins to occur around $10{ }^{\circ} \mathrm{C}$ for the neat polyester, the $30 \mathrm{vol} \%$ fique fabric composite remains stiffer up to $40{ }^{\circ} \mathrm{C}$. As the temperature increases, there is a rapid decrease in the $\mathrm{E}^{\prime}$ value from about $40{ }^{\circ} \mathrm{C}$ until a plateau of less than $100 \mathrm{MPa}$ is reached.

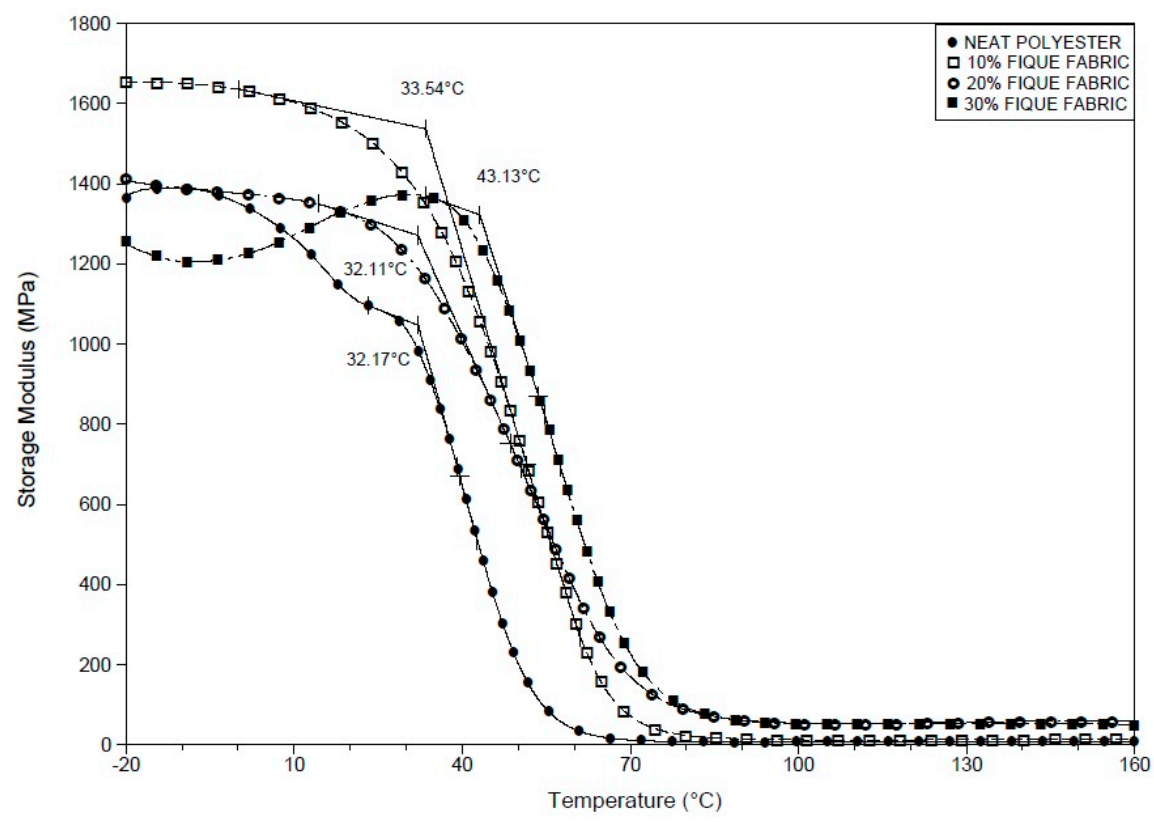

Figure 3. Storage modulus $\left(\mathrm{E}^{\prime}\right)$ curves for the neat polyester resin and for the composites reinforced with fique fabric.

Figure 4 compares the variation of the loss modulus ( $\left.E^{\prime \prime}\right)$ with temperature for the neat polyester resin and the investigated composites. All of the curves of this figure go through a well-defined maximum value that can be associated with the relaxation peak $\alpha$ [43]. This relaxation is attributed to the mobility of the chains in the crystalline phase of the polymer, which in this work is the polyester matrix [44]. For the fique fabric composites, the peaks $\alpha$ in the $\mathrm{E}^{\prime \prime}$ curves are shifted by about $15{ }^{\circ} \mathrm{C}$ for higher temperatures. Kalusuraman et al. [43] suggested that the $\alpha$ peaks in $\mathrm{E}^{\prime \prime}$ could be related to the onset of the glass transition temperature $\left(T_{\mathrm{g}}\right)$ of the polymeric matrix. Therefore, the results in Figure 4 revealed that the incorporation of fique fabric restrains the mobility of the polyester chains and retards the formation of an amorphous structure. This mechanism also explains the relative shift to higher temperature $\left(10\right.$ to $40^{\circ} \mathrm{C}$ ) of the fique fiber composites viscoelastic softening, Figure 3 , as compared to the neat polyester. 


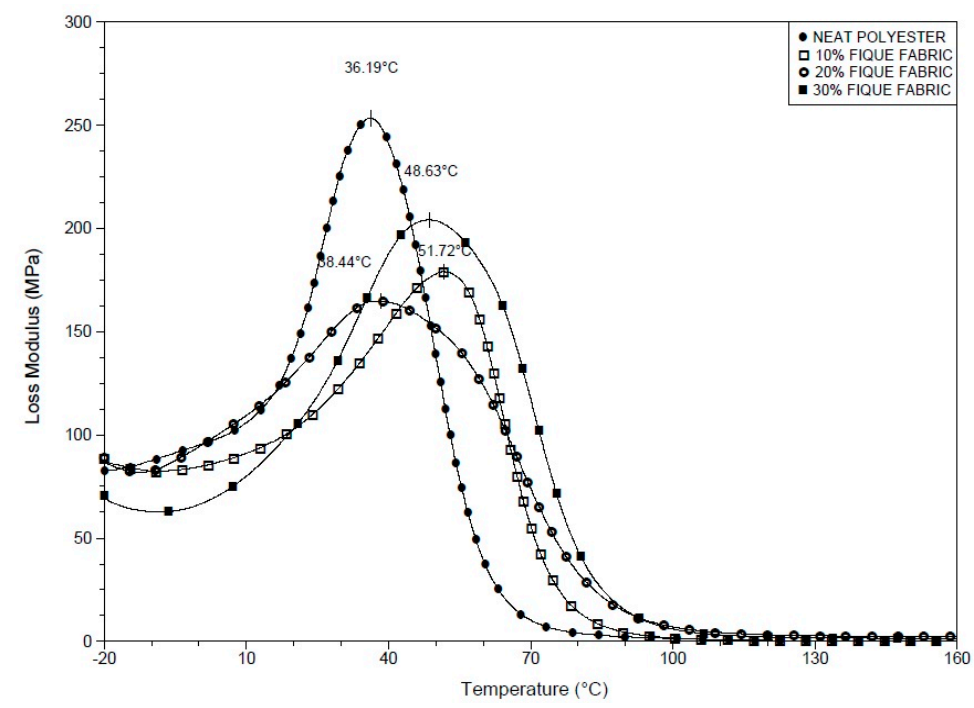

Figure 4. Loss modulus (E") curves for the neat polyester resin and for the composites reinforced with fique fabric.

The variation of the tan $\delta$ with the temperature for the neat polyester resin and the composites incorporated with fique fabric is shown in Figure 5. It can be seen in this figure that the composites exhibit peaks with lower amplitude and shifted to relatively higher temperatures as compared to the neat polyester resin. This suggests, as also observed for the storage modulus in Figure 3 and loss modulus in Figure 4, that the fique fabric effectively interacts with the polyester matrix chains, impairing their mobility and reducing their structural damping ability. The tan $\delta$ peaks are attributed to the upper limit of $T_{\mathrm{g}}$ [43]. Moreover, the decrease in peak amplitude and increase in temperature, Figure 5 , also suggest a higher attenuation in internal vibration and a shift to higher temperature of $T_{\mathrm{g}}$ with the increasing amount of fique fabric in the polyester matrix. Consequently, the results in Figure 5 indicate that the incorporation of fique fabric not only reduces the mobility of the polyester chains, but also prevents the disruption of their structural organization. Consequently, the end of the polyester matrix transition from the glass to the rubbery state could occur at higher temperatures.

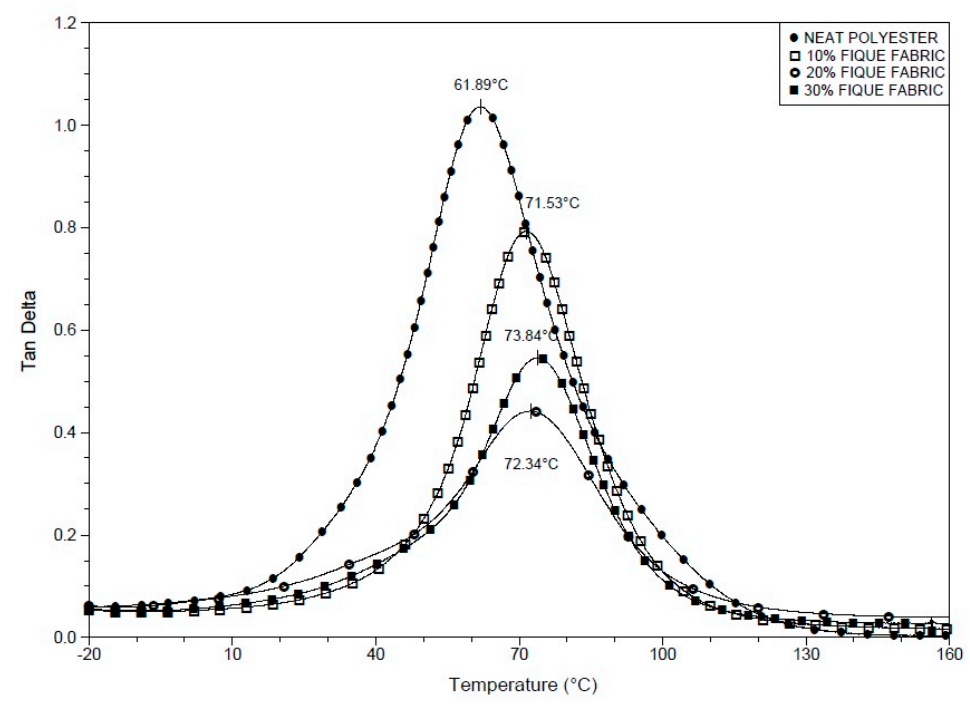

Figure 5. Tan $\delta$ curves for the neat polyester resin and for the composites reinforced with fique fabric. 


\subsection{Ballistic Tests}

Table 1 presents the average depth measured in the clay witness for the different MAS targets investigated. For application in armor vests, the fique fabric composite is lighter and significantly cheaper than the Kevlar ${ }^{\mathrm{TM}}$. These are factors that are further discussed and might play practical advantages in considering the substitution of fique fabric composites for Kevlar ${ }^{\mathrm{TM}}$ in an MAS for personal protection against high velocity projectiles, such as the $7.62 \times 51 \mathrm{~mm}$ projectile.

Table 1. Average depth of penetration in the clay witness backing different MAS of fique fabric composites.

\begin{tabular}{cc}
\hline Intermediate Layer Material & Depth of Penetration $(\mathbf{m m})$ \\
\hline 10 vol \% fique fabric & $17 \pm 3$ \\
20 vol \% fique fabric & $15 \pm 3$ \\
Kevlar $^{\mathrm{TM}}$ & $23 \pm 3[45]$ \\
\hline
\end{tabular}

Figure 6a illustrates the aspect of the different MAS targets after the ballistic tests. In Figure 6b, it can be seen that the ceramic has disappeared by complete shattering.
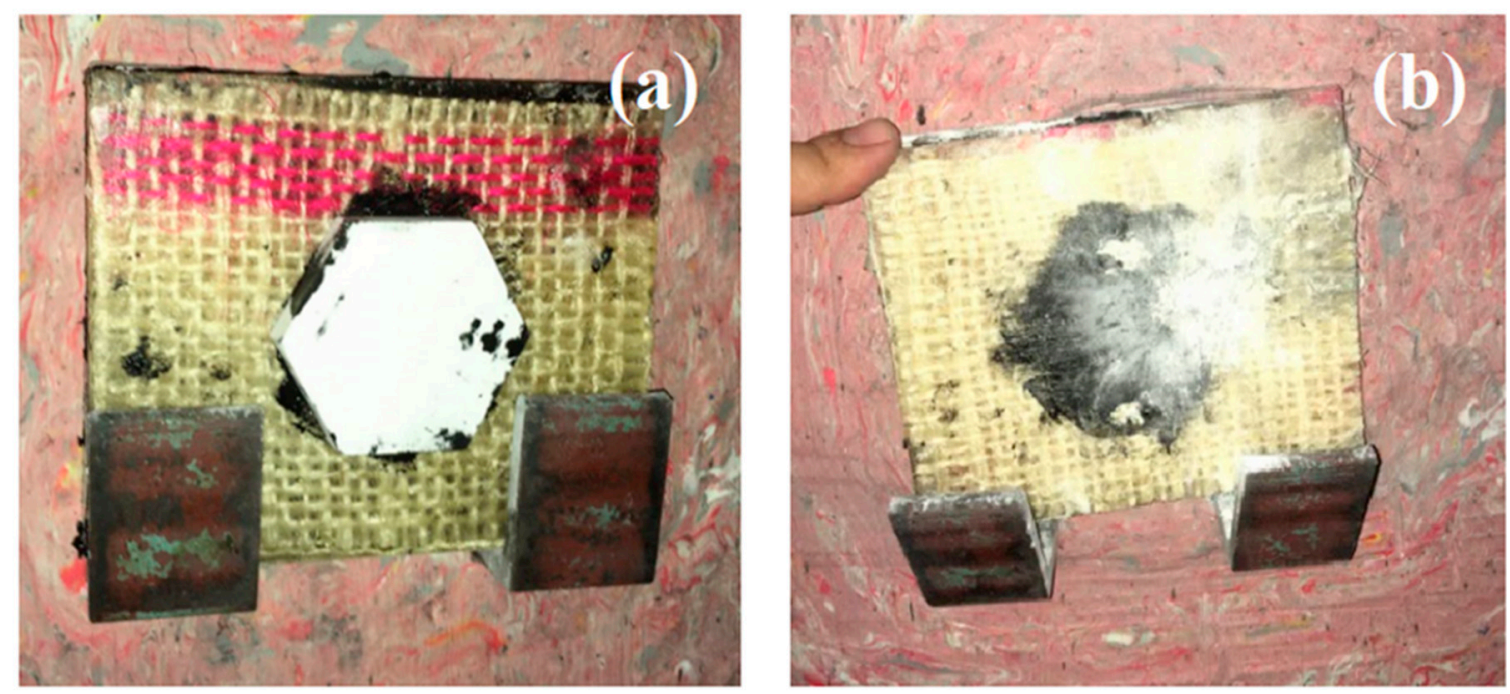

Figure 6. Typical aspect before (a) and after (b) ballistic test of MAS targets with a second layer of fique fabric-reinforced polyester composite.

After ballistic tests, the fracture surface of MAS components were observed by SEM. Figure 7a shows the expected inter-crystalline brittle fracture surface of a collected macroscopic ceramic particle, which is almost splitting into microscopic fragments associated with grains. As indicated by Medvedovski [46], a $7.62 \mathrm{~mm}$ projectile causes different kinds of cracks to be formed during the impact. Figure $7 \mathrm{~b}$ shows the ability of the $20 \mathrm{vol} \%$ fique fabric composite second layer, in an MAS with a ceramic front, to collect fragments generated from the ballistic impact shown in Figure 7a. This ability does not require stronger fibers but mechanisms of mechanical incrustation as well as fragment attraction by Van der Waals forces and static charges on the fiber surface, of either synthetic Kevlar $^{\mathrm{TM}}$ [47] or natural fiber-based composites [28-33]. 

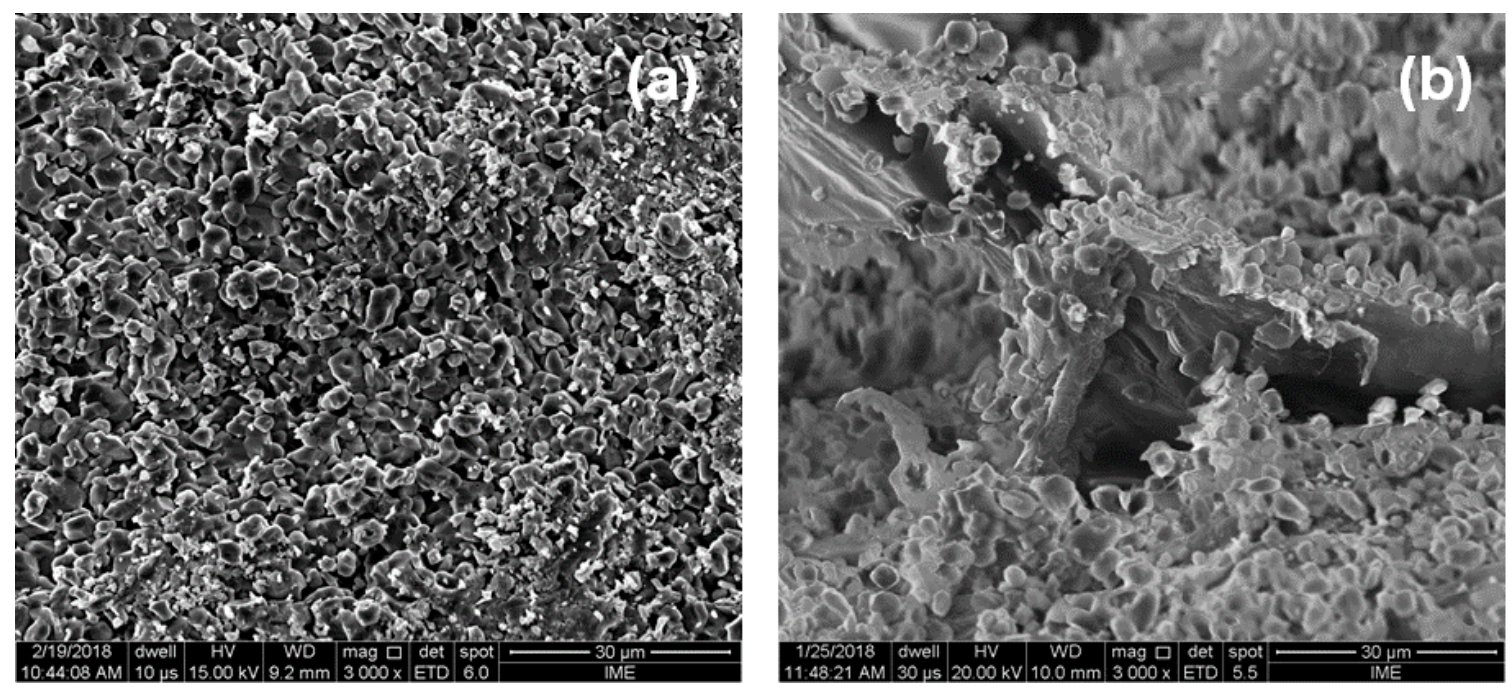

Figure 7. (a) Fracture surface of a particle from the ceramic after the ballistic test and (b) fracture surface of $20 \mathrm{vol} \%$ fique fabric composite covered with ceramic fragments.

\subsection{Cost Comparison}

A cost model associated with the use of fique fabric composites in comparison to conventional engineering composites is presented in Table 2. The basic costs were obtained from the literature for polyester, epoxy, aramid laminates $\left(\operatorname{Kevlar}^{\mathrm{TM}}\right)$, and glass fiber [48], as well as for fique fiber /fabric [49] and for sisal, jute, curaua, and piassava [50].

Table 2. Cost model for different fabric composites.

\begin{tabular}{ccc}
\hline Composite Material & Cost (US\$/Kg) & Reference \\
\hline 64.8 vol \% aramid laminate/epoxy & 49.59 & {$[48]$} \\
72 vol \% glass fiber/epoxy & 18.06 & {$[48]$} \\
30 vol \% sisal fiber/polyester & 3.23 & {$[49]$} \\
30 vol \% jute fiber/polyester & 3.24 & {$[50]$} \\
30 vol \% curaua fiber/polyester & 3.19 & {$[50]$} \\
30 vol \% piassava fiber/polyester & 3.21 & {$[50]$} \\
20 vol \% fique fabric/polyester & 3.61 & Present Work \\
30 vol \% fique fabric/polyester & 3.26 & Present Work \\
\hline
\end{tabular}

In this table, is it shown that Kevlar ${ }^{\mathrm{TM}}$ (aramid fiber laminate) is the most expensive composite, more than 13 times the price of any common natural fiber composite, including the presently investigated fique composites. Even a less expensive glass fiber composite is more than five times as costly as any natural fiber composite. Therefore, the incorporation of any common natural fiber-based material, including fique fabric, reduces the price of the composite.

\section{Summary and Conclusions}

- The introduction of fique fabric raises the viscoelastic stiffness level and tends to shift the curves of the storage modulus $\left(\mathrm{E}^{\prime}\right)$ to higher temperatures. This leads to a delay in the onset of the thermal softening of the composite. The peak $\alpha$ of the loss modulus ( $\left.\mathrm{E}^{\prime \prime}\right)$ is also shifted to higher glass transition temperatures $\left(T_{\mathrm{g}}\right)$, indicating less mobility in the polyester resin chains of the matrix by interaction with the fique fabric. The maximum in $\tan \delta$ curves, associated with end of $T_{\mathrm{g}}$, suffers not only a reduction in its amplitude but also a shift towards higher temperatures with the introduction of fique fabric. Hence, a high attenuation of internal vibration and increase in $T_{\mathrm{g}}$ occur with an increasing amount of fique fabric in the polyester matrix. 
- A multilayered armor system (MAS), in which conventional Kevlar ${ }^{\mathrm{TM}}$ was replaced by a polyester matrix composite reinforced with 10 or $20 \mathrm{vol} \%$ of fique fabric as second layers, attended the NIJ trauma limit after ballistic tests with $7.62 \mathrm{~mm}$ ammunition. The depth of penetration into $20 \mathrm{vol} \%$ fique fabric composite, $15 \mathrm{~mm}$, demonstrated this composite to be more efficient than conventional Kevlar ${ }^{\mathrm{TM}}$ with $23 \mathrm{~mm}$ as a second MAS layer.

- More than ballistic performance, the significantly lower cost in association with the environmental and societal benefits of using a natural material favor the substitution of fique fabric composite as an MAS second layer. As an economical advantage, armor vests with fique fabric composites would be 13 times cheaper than similar ones made with Kevlar ${ }^{\mathrm{TM}}$.

Acknowledgments: The authors acknowledge the support to this investigation by the Brazilian agencies: Conselho Nacional de Desenvolvimento Científico e Tecnológico, CNPq; Coordenação de Aperfeiçoamento de Pessoal de Nível Superior, CAPES; and Fundação de Amparo à Pesquisa do Estado do Rio de Janeiro, FAPERJ.

Author Contributions: Sergio Neves Monteiro conceived and Artur Camposo Pereira designed the experiments; Noan Tonini Simonassi and Foluke Salgado de Assis performed the experiments; Ricardo Pondé Weber and Carlos Luiz Ferreira analyzed the data; Michelle Souza Oliveira contributed with specimen fabrication; Henry A. Colorado contributed with materials; Sergio Neves Monteiro wrote the paper.

Conflicts of Interest: The authors declare no conflict of interest.

\section{References}

1. Mohanty, A.K.; Misra, M.; Drzal, L.T. Sustainable Bio-Composites from Renewable Resources: Opportunities and Challenges in the Green Materials World. J. Polym. Environ. 2002, 10, 19-26. [CrossRef]

2. Netravali, A.N.; Chabba, S. Composites get greener. Mater. Today 2003, 6, 22-29. [CrossRef]

3. Crocker, J. Natural materials innovative natural composites. Mater. Technol. 2008, 2-3, 174-178. [CrossRef]

4. John, M.J.; Thomas, S. Biofibres and biocomposites. Carbohydr. Polym. 2008, 71, 343-364. [CrossRef]

5. Monteiro, S.N.; Lopes, F.P.D.; Ferreira, A.S.; Nascimento, D.C.O. Natural-fiber polymer-matrix composites: Cheaper, tougher, and environmentally friendly. JOM 2009, 61, 17-22. [CrossRef]

6. Satyanarayana, K.G.; Arizaga, G.G.; Wypych, F. Biodegradable composites based on lignocellulosic fibers-An overview. Prog. Polym Sci. 2009, 34, 982-1021. [CrossRef]

7. Monteiro, S.N.; Lopes, F.P.D.; Barbosa, A.P.; Bevitori, A.B.; Silva, I.L.A.; Costa, L.L. Natural lignocellulosic fibers as engineering materials-An overview. Metall. Mater. Trans. A 2011, 42, 2963-2974. [CrossRef]

8. Faruk, O.; Bledzki, A.K.; Fink, H.P.; Sain, M. Biocomposites reinforced with natural fibers: $2000-2010$. Progr. Polym. Sci. 2012, 37, 1555-1596. [CrossRef]

9. Thakur, V.K.; Thakur, M.K.; Gupta, R.K. Review: Raw natural fiber-based polymer composites. Int. J. Polym. Anal. Charact. 2014, 19, 256-271. [CrossRef]

10. Pappu, A.; Patil, V.; Mahindrakar, A.; Haque, R.; Thakur, V.K. Advances in industrial prospective of cellulosic macromolecules enriched banana biofibre resources: A review. Int. J. Biol. Macromol. 2015, 79, 449-458. [CrossRef] [PubMed]

11. Thakur, M.K.; Thakur, V.K.; Gupta, R.K.; Pappu, A. Synthesis and applications of biodegradable soy based graft copolymers: A review. ACS Sustain. Chem. Eng. 2016, 4, 1-17. [CrossRef]

12. Güven, O.; Monteiro, S.N.; Moura, E.A.B.; Drelich, J.W. Re-emerging field of lignocellulosic fiber-polymer composites and ionizing radiation technology in their formulation. Polym. Rev. 2016, 56, 702-736. [CrossRef]

13. Pappu, A.; Saxena, M.; Thakur, V.K.; Sahrma, A.; Haque, R. Facile extraction, processing and characterization of biorenewable sisal fibers for multifunctional applications. J. Macromol. Sci. Part A 2016, 53, 424-432. [CrossRef]

14. Pickering, K.L.; Efendy, M.G.A.; Le, T.M. A review of recent developments in natural fibre composites and their mechanical performance. Compos. Part A Appl. Sci. Manuf. 2016, 83, 98-112. [CrossRef]

15. Pappu, A.; Thakur, V.K. Towards sustainable micro and nano composites from fly ash and natural fibers for multifunctional applications. Vacuum 2017, 146, 375-385. [CrossRef]

16. Wambua, P.; Ivens, I.; Verpoest, I. Natural fibers: Can they replace glass in fiber reinforced plastics. Compos. Sci. Technol. 2003, 63, 1259-1264. [CrossRef] 
17. Monteiro, S.N.; Milanezi, T.L.; Louro, L.H.L.; Lima, E.P., Jr.; Braga, F.O.; Gomes, A.V.; Drelich, J.W. Novel ballistic ramie fabric composite competing with Kevlar-fabric in multilayered armor. Mater. Des. 2016, 96, 263-269. [CrossRef]

18. Holbery, J.; Houston, D. Natural-fiber-reinforced polymer composites in automotive applications. JOM 2006, 58, 80-86. [CrossRef]

19. Zah, R.; Hischier, R.; Leão, A.L.; Braun, I. Curauá fibers in the automobile industry-A sustainability assessment. J. Clean. Prod. 2007, 15, 1032-1040. [CrossRef]

20. Thomas, N.; Paul, S.A.; Pothan, L.A.; Deepa, B. Natural Fibers: Structure, Properties and Applications. In Cellulose Fibers: Bio- and Nano-Polymer Composites, 1st ed.; Kalia, S., Kaith, B.S., Kaur, I., Eds.; Springer: Berlin/Heidelberg, Germany, 2011; pp. 3-42.

21. DeLuca, E.; Prifti, J.; Betheney, W.; Chou, S.C. Ballistic impact damage of S2-glass-reinforced plastic structural armor. Compos. Sci. Technol. 1998, 58, 1453-1461. [CrossRef]

22. Nunes, L.M.; Paciornik, S.; d'Almeida, J.R.M. Evaluation of the damaged area of glass-fiber-reinforced epoxy-matrix composite materials submitted to ballistic impacts. Compos. Sci. Technol. 2004, 64, 945-954. [CrossRef]

23. Hosur, M.V.; Vaidya, U.K.; Ulven, C.; Jeelani, S. Performance of stitched/unstitched woven carbon/epoxy composites under high velocity impact loading. Compos. Struct. 2004, 64, 455-466. [CrossRef]

24. Lee, Y.S.; Wetzel, E.D.; Wagner, N.J. The ballistic impact characteristic of Kevlar ${ }^{\circledR}$ woven fabrics impregnated with a colloidal shear thickening fluid. J. Mater. Sci. 2003, 38, 2825-2833. [CrossRef]

25. Jacobs, M.J.N.; Van Dingenen, J.L.J. Ballistic protection mechanisms in personal armor. J. Mater. Sci. 2001, 36, 3137-3142. [CrossRef]

26. Lee, B.L.; Song, J.W.; Ward, J.E. Failure of Spectra ${ }^{\circledR}$ polyethylene fiber-reinforced composites under ballistic impact loading. Compos. Mater. 1994, 28, 1202-1226. [CrossRef]

27. Morye, S.S.; Hine, P.J.; Duckett, R.A.; Carr, D.J.; Ward, I.M. Modeling of the energy absorption by polymer composites upon ballistic impact. Compos. Sci. Technol. 2000, 60, 2631-2642. [CrossRef]

28. Rohen, L.A.; Margem, F.M.; Monteiro, S.N.; Vieira, C.M.F.; Araujo, B.M.; Lima, E.S. Ballistic efficiency of an individual epoxy composite reinforced with sisal fibers in multilayered armor. Mater. Res. 2015, 18, 55-62. [CrossRef]

29. Monteiro, S.N.; Louro, L.H.L.; Trindade, W.; Elias, C.N.; Ferreira, C.L.; Lima, E.S.; Weber, R.P.; Suarez, J.M.; Figueiredo, A.B.S.; Pinheiro, W.A.; et al. Natural curaua fiber-reinforced composites in multilayered ballistic armor. Metall. Mater. Trans. A 2015, 46, 4567-4577. [CrossRef]

30. Cruz, R.B.; Lima, E.P., Jr.; Monteiro, S.N.; Louro, L.H.L. Giant bamboo fiber reinforced epoxy composite in multilayered ballistic armor. Mater. Res. 2015, 18, 70-75. [CrossRef]

31. Da Luz, F.S.; Lima, E.P., Jr.; Louro, L.H.L.; Monteiro, S.N. Ballistic test of multilayered armor with intermediate epoxy composite reinforced with jute fabric. Mater. Res. 2015, 18, 170-177. [CrossRef]

32. Monteiro, S.N.; Braga, F.O.; Lima, E.P., Jr.; Louro, L.H.L.; Drelich, J.W. Promising curaua fiber-reinforced polyester composite for high-impact ballistic multilayered armor. Polym. Eng. Sci. 2016, 57, 947-954. [CrossRef]

33. Nascimento, L.F.C.; Holanda, L.I.F.; Louro, L.H.L.; Monteiro, S.N.; Gomes, A.V.; Lima, E.P., Jr. Natural Mallow Fiber-Reinforced Epoxy Composite for Ballistic Armor Against Class III-A Ammunition. Metall. Mater. Trans. A 2017, 48, 4425-4431. [CrossRef]

34. Gañan, P.; Mondragon, I. Surface modification of fique fibers. Effect on their physico-mechanical properties. Polym. Compos. 2002, 23, 383-394. [CrossRef]

35. Gañan, P.; Mondragon, I.J. Thermal and degradation behaviour of fique fiber reinforced thermoplastic matrix composites. Therm. Anal. Calorim. 2003, 73, 783-795. [CrossRef]

36. Altoe, G.R.; Netto, P.A.; Barcelos, M.; Gomes, A.; Margem, F.M.; Monteiro, S.N. Bending mechanical behavior of polyester matrix reinforced with fique fiber. In Characterization of Minerals, Metals and Materials; John Wiley \& Sons: Hoboken, NJ, USA, 2015; pp. 117-121.

37. Altoe, G.R.; Netto, P.A.; Teles, M.C.A.; Daniel, G.; Margem, F.M.; Monteiro, S.N. Tensile strength of polyester composites reinforced with fique fibers. In Characterization of Minerals, Metals and Materials; John Wiley \& Sons: Hoboken, NJ, USA, 2015; pp. 465-470. 
38. Altoe, G.R.; Netto, P.A.; Teles, M.C.A.; Borges, L.G.X.; Margem, F.M.; Monteiro, S.N. Tensile strength of epoxy composites reinforced with fique fibers. In Characterization of Minerals, Metals and Materials; John Wiley \& Sons: Hoboken, NJ, USA, 2016; pp. 391-396.

39. Netto, P.A.; Altoe, G.R.; Margem, F.M.; Braga, F.O.; Monteiro, S.N.; Margem, I.M. Correlation between the Density and the Diameter of Fique Fibers. Mater. Sci. Forum 2016, 869, 377-383. [CrossRef]

40. Monteiro, S.N.; Calado, V.; Rodriguez, R.J.S.; Margem, F.M.J. Thermogravimetric stability of polymer composites reinforced with less common lignocellulosic fibers-An overview. Mater. Res. Technol. 2012, 1, 117-126. [CrossRef]

41. Abrate, S. Ballistic Impact on Composite Structures, 1st ed.; Cambridge University Press: Cambridge, UK, 1998; pp. 215-220.

42. Tasdemirci, A.; Tunusoglu, G.; Guden, M. The effect of the interlayer on the ballistic performance of ceramic/composite armors: Experimental and numerical study. Int. J. Impact Eng. 2012, 44, 1-9. [CrossRef]

43. Kalusuraman, G.; Siva, I.; Winowlin Jappes, J.T.; Gao, X.-Z.; Amico, S.C. Fibre loading effects on dynamic mechanical properties of compression moulded luffa fibre polyester composites. Int. J. Comput. Aided Eng. Technol. 2018, 10, 157-165. [CrossRef]

44. Mohanty, S.; Verma, S.K.; Nayak, S.K. Dynamic mechanical and thermal properties of MAPE treated jute/HDPE composites. Compos. Sci. Technol. 2006, 66, 538-547. [CrossRef]

45. Luz, F.S.; Junior, E.P.L.; Louro, L.H.L.; Monteiro, S.N. Ballistic Test of Multilayered Armor with Intermediate Epoxy Composite Reinforced with Jute Fabric. Mater. Res. 2015, 18, 170-177. [CrossRef]

46. Medvedovski, E. Ballistic performance of armor ceramics: Influence of design and structure. Part 2. Ceram. Int. 2010, 36, 2117-2127. [CrossRef]

47. Monteiro, S.N.; Lima, E.P., Jr.; Louro, L.H.L.; Silva, L.C.; Drelich, J.W. Unlocking function of aramid fibers in multilayered ballistic armor. Metall. Mater. Trans. A 2015, 46, 37-40. [CrossRef]

48. Callister, W.D., Jr.; Rethwisch, D.G. Materials Science and Engineering: An Introduction, 9th ed.; John Wiley \& Sons: Hoboken, NJ, USA, 2014; pp. 911-915.

49. Castellanos, O.F.; Torres, L.M.; Roja, J.C. Definition of a Prospective Agenda for Investigation in the Productive Agroindustrial Chain of Fique from Technological Intelligence Systems (in Spanish), 2009. Available online: http://www.bdigital.unal.edu.co/2078/1/2009_Agenda_Fique.pdf (accessed on 10 January 2018).

50. Companhia Nacional de Abastecimento (CONAB-2017). 2017. Available online: http://sisdep.conab.gov.br/ precosiagroweb/ (accessed on 6 December 2017). (In Portuguese) 